\section{anthropology} \& materialism

\section{Anthropology \& Materialism}

A Journal of Social Research

1 | 2013

Across the Fields

\title{
Toward a Negative Anthropology
}

Critical Theory's Altercations with Philosophical Anthropology

Vers une anthropologie négative. La théorie critique en conflit avec

l'anthropologie philosophique

Hacia una antropología negativa. La teoría crítica en conflicto con antropología filosófica

\section{Dennis Johannssen}

\section{(2) OpenEdition}

\section{Journals}

Electronic version

URL: http://journals.openedition.org/am/194

DOI: $10.4000 / a m .194$

ISSN: 2364-0480

Publisher:

CETCOPRA, CRASSH - Center for Research in the Arts Social Sciences and Humanities, Fakultät Gestaltung - Universität der Künste Berlin

\section{Electronic reference}

Dennis Johannssen, «Toward a Negative Anthropology », Anthropology \& Materialism [Online], 1 | 2013, Online since 15 October 2013, connection on 30 April 2019. URL : http://journals.openedition.org/ am/194; DOI : 10.4000/am.194

This text was automatically generated on 30 April 2019.

Tous droits réservés 


\title{
Toward a Negative Anthropology
}

\author{
Critical Theory's Altercations with Philosophical Anthropology \\ Vers une anthropologie négative. La théorie critique en conflit avec \\ l'anthropologie philosophique \\ Hacia una antropología negativa. La teoría crítica en conflicto con antropología \\ filosófica
}

Dennis Johannssen

\section{Introduction}

1 From its inception, the Frankfurt School was sceptical of the new momentum anthropological thought gained during the Weimar Republic. Although its members were by and large committed to the idea of the human being's permanent self-realization in history, which led them to reject every doctrine of man's invariant characteristics, they nevertheless differed significantly on their willingness to integrate anthropological assumptions into their individual work. Max Horkheimer, for instance, explicitly granted philosophical anthropology an auxiliary role for Critical Theory in his essays from the mid-1930s, and he relied heavily on contemporary ethnology and anthropology in the first chapter of the Dialectic of Enlightenment.

2 Theodor W. Adorno, a relentless opponent of all shades of anthropological philosophy, repeatedly took issue with Walter Benjamin's "anthropological materialism", and dismissed philosophical anthropology tout court in his Negative Dialectics. Ulrich Sonnemann, a friend of Adorno's and one of the last representatives of the first generation, published his main work, Negative Anthropologie in 1969. Providing "preliminary studies on the sabotage of fate," as the subtitle reads, he called for a permanent revolution against any total theory of man. Beyond Sonnemann's specific understanding, his notion of "negative anthropology" serves well to characterise Critical Theory's ambiguous altercations with anthropological philosophy. ${ }^{1}$

3 Despite their differences in detail, Horkheimer, Adorno and Sonnemann were unanimous in their refusal to ask or answer the question "What is man?" - and indeed to make any 
positive assumptions about the essence of man. ${ }^{2}$ Broadly conceived, negative anthropology rests on this abstention from judgment; it originates in Marx's (1978: 145) understanding of human essence as "the ensemble of the social relations", but as part of a critical social and cultural theory it is not limited to ex negativo determinations. By understanding the human being as the ensemble of what it is not, or what it failed to make of itself, negative anthropology resists the demand of spelling out what man can or should be, while holding on to the possibility of realising happiness and abandoning suffering in history. ${ }^{3}$

4 The idea of permanent anthropogenesis salvaged by negative anthropology requires a ban on any anthropological point of view that holds human essence fixed across historical epochs. ${ }^{4}$ By and large, all representatives of the early Frankfurt School share this verdict. ${ }^{5}$ During the 1920s and 1930s, renewed interest in anthropology prompts Horkheimer and Adorno to re-evaluate the status and legitimacy of anthropological principles and assumptions. It is not until the late 1960s, however, that Sonnemann explicitly addresses the relationship between Critical Theory and philosophical anthropology.

\section{Horkheimer. The Critique of the Invariant}

5 Horkheimer was highly sceptical of theoretical anthropology and certainly never proposed an identifiable or programmatic philosophical anthropology himself. However, he dealt explicitly with anthropology in his "Remarks on Philosophical Anthropology" from 1935. He argues that "Modern philosophical anthropology stems from precisely the same need that the idealist philosophy of the bourgeois era tried to satisfy from its inception: namely to lay down new, absolute principles that provide the rationale for action" (1995: 153-154). Horkheimer focuses on the relation between anthropological assumptions and the absolute principles that serve to legitimate forms of sovereignty. $\mathrm{He}$ points out that the strength and danger of philosophical anthropology lies in the absoluteness of its answers, and that assumptions about man as such are powerful instruments for the constitution of society's moral substance.

Horkheimer (1995: 156) takes issue with Max Scheler's philosophical anthropology. He worries that the concept of essence, or "Wesen", that the phenomenological method tries to determine, implies the idea of determination or destiny. "The desire to provide a foundation for action by way of insights into human nature (feste Wesenheiten) has motivated phenomenology since its beginning." The universality of things can never be perfectly represented by their particular existence. Because existing particulars can be classified and subsumed under concepts, they always refer to the possibility of a higher, more complete reality (Marcuse 1936: 3). This idea of a general historical determination of man implicit in the concept of human essence is what Horkheimer rejects. The discrepancy of what is and what should be is measured by the eidos of man's possible perfection implied by the concept of essence.

7 Social philosophy, as Horkheimer understands it, has to oppose such teleological determinations. Philosophical notions of man's ideal condition are always determined by the present social circumstances. Critical Theory, on the contrary, "does not provide the grounds for meaning and an eternal purpose. [...] A theory free from illusions can only conceive of human purpose negatively, and reveals the inherent contradictions between the conditions of existence and everything that the great philosophies have postulated as a purpose" (Horkheimer 1995: 156-157). 
8 To speak only negatively about the human being means not to prescribe what it can or should be, but to account for what it lacks under the prevailing social conditions. Possible references for such philosophical work include deprivation, economic inequality, hardship and the like, which can be empirically analysed in the past and present. Future ideals like the idealist dictum of an absolute unfolding of the human being's dispositions can only serve as negative references that reveal the defects and contradictions of society's actual condition.

But there is not only hardship and misery. History also contains traces of liberation in the revolutionary movements of the past. In the words of the early Marx, the human being has not yet come into being, because to the present day its species characteristics - the characteristics that result from the historical form of his conscious relation to nature by means of labour - have been restricted by repressive forms of social organisation (Marx 1988: 75-77; Bien 1984: 65-77, 201-217). Horkheimer is not willing to give up the anthropological assumptions implied by this model of man's progressive historical realisation, for it allows him to justify a universal, trans-historical demand of the human being to be liberated from repressive social conditions.

10 However, if the external social world that shapes the human being changes over the course of history, there can be no undeviating, unified human essence. But only because the concept of human essence cannot lend meaning to history, "Anthropological studies [...] do not have to be worthless (wertlos); they can extend and refine the understanding of historical tendencies. They would then be concerned with historically determined human beings and groups of human beings instead of with man as such, and would seek to understand their existence and development not as isolated individuals but rather as integral parts of the life of society" (1995: 161; transl. changed).

11 Horkheimer eventually grants anthropology some legitimacy, as he does not counter it with absolute negativity. As a "reactive philosophical discipline" (Habermas 1973: 92), philosophical anthropology cannot claim to be value-free, and Horkheimer (1995: 159) sees Scheler aligning with Critical Theory on this point. Because the human being universally deserves to be liberated from suffering, Horkheimer's (1995: 175; transl. changed) negative anthropology cannot be entirely negative: "The denial of an unchanging, constant human nature should, on the other hand, not be taken as an absolute to the extent that the belief in a universal human nature appears at times as the lesser of two evils. One must also recognise that happiness and misery run constantly through history; that human beings as they are have their limits and deserve consideration."

12 Not unlike Benjamin, Horkheimer allows for a minimum of positive anthropology in order to mobilise the efforts of failed revolutions for the present. The determination of man's essence as deserving to be relieved from suffering, however, does not hold for every historical epoch, but only for the present in respect to the development of bourgeois society - in respect to what Marx called the "prehistory of human society" (Marx 1992: 426). If the concept of an unchangeable and unitary human essence were abandoned entirely, man's present right to freedom from repression would be negated as well.

13 Over two decades later, in 1957, Horkheimer again picks up the "Concept of Man" as a philosophical problem in his contribution to the Festschrift for Helmuth Plessner. Spelling out the theoretical reflections of his "Remarks", he discusses how the socio-economic 
changes in the fields of education, family, technology, labour conditions, relations of generation, sex and age groups affect the individual, and consequently the way in which the human being presents itself to philosophical inquiry. Horkheimer's (1974: 14-15) theoretical position compared with that of 1935 seems almost unchanged. A "static conception" of man is impossible because of the individual's dependency on its social and cultural circumstances. "For however much history may depend on individuals [...], it remains true that man's makeup is itself a product of his history." For Horkheimer, only the "rational spontaneity of society", which is the objectified critical subjectivity of the individual itself, is capable of penetrating the veiled correlation between society and the individual. Critical philosophy's task is to gain precise knowledge of the irrational in society, which is particularly important in view of any "naturalistic anthropology" that propels the degeneration (Reprimitivierung) of human history back into natural history by reinforcing the strength and power of those who are already economically the strongest.

To explain the way in which the human being can be studied in accordance with Critical Theory, Horkheimer (1974: 27) quotes from Adorno's "Sociology and Psychology" (1967: 77): "The isolated individual, the pure subject of self-preservation, embodies in absolute opposition to society its innermost principle. The jarring elements that make up the individual, his 'properties', are invariably also moments of the social totality. $\mathrm{He}$ is, in the strict sense, a monad, representing the whole and its contradictions, without, however, being at anytime conscious of the whole." The "trait of anthropology, [...] the constitution of people as they in fact exist in our society" (Adorno 2003: 30) is the imprint society leaves on the inner constitution of the isolated subject. The monadic subject is unable to recognise the totality of which it is a part. However, the epoch's social and economic laws are covertly inscribed in its inner constitution, and this structural correspondence between subject and world allows for sociology and psychology to consider the individual as a seismograph for society's development as a whole. But this is it. Horkheimer and Adorno agree that human "essence" is nothing but the distorted and unconscious reflection of its social-historical circumstances.

Unlike Adorno, however, Horkheimer does not repudiate philosophical anthropology entirely. Instead, his discussions expose elements of a negative dialectical anthropology. ${ }^{6}$ He engages with the tasks and predicaments of philosophical anthropology, and he accepts a minimum of positive anthropological assumptions for the programme of Critical Theory - a concession that Adorno is not willing to make.

\section{Adorno. The Verdict on First Nature}

Adorno's Negative Dialectics (1983: 124) contains a radical dismissal of anthropological philosophy. The word "man" (Mensch), he writes, is a synonym for existence "in demagogic jargon." He dismisses anthropological philosophy as a whole, including versions restricted to the human being as it is. "We cannot say what man is. Man today is a function, unfree, regressing behind whatever is ascribed to him as invariant [...]. To decipher the human essence by the way it is now would sabotage its possibility." Even anthropology's attempt at turning indeterminacy into a primary principle - something that could count as negative anthropology's positive element - falls under Adorno's verdict. By granting man his coming into being (Gewordensein) and conditionality ( Bedingtheit) as abstract qualities, "historical anthropology" ignores man's actual historical condition - the "social heritage of the mutilations inflicted upon him over 
thousands of years" as well as "the dehumanisation that has made the subjects what they are" (ibid.; transl. changed).

Adorno launches a coup de grâce against anthropological philosophy to push anthropology even further into its "proper realms" of "positivist ethnology and sociological cultural anthropology" (Adorno 1970: 262-263; own translation). In its process of retreat, philosophical anthropology tried to survive by defining the human being as open and essentially indefinable. "The thesis of new-fangled anthropology that man is open [...] is empty; it passes off its own indeterminacy [...] as something determinate and positive." 8 Philosophy becomes apologetic in the moment it apprehends the individual as anything but a disfigured expression of reified social relations. In Adorno's eyes, anthropological philosophy does not gain any legitimacy by conceding that man cannot be defined: "That we cannot say what man is does not establish a particularly majestic anthropology; it vetoes any anthropology" (Adorno 1983: 124; transl. changed). ${ }^{9}$

Contrary to his radical dismissal in the passages from Negative Dialectics, Adorno grants "dialectical anthropology" an important role in his Lectures on Negative Dialectics. During his discussion of the relationship between theory and praxis, he states that the question why the proletarian revolution "did not and why it could not happen" belongs to "a dialectical anthropology which is assuredly no small part of the problem of philosophy in our time" (Adorno 2008: 46). A series of reflections from the 1940s, published under the title "Individuum und Gesellschaft", indicate what such a dialectical anthropology might look like. ${ }^{10}$

19 Commenting on these fragments, Rolf Tiedemann supposes that Horkheimer and Adorno never published a book based on this material because of the "general critique of any non-historical anthropology that postulates a human essence as such, a critique that is already presented in Horkheimer's 'Remarks' [...]. While traditional anthropology, for instance Max Scheler, departs from unitary basic structures of the human being ( Menschsein), a materialist anthropology, which could have been the only anthropology pursuable by Critical Theory, would address the historically changeable human nature. Except for the name, a materialist anthropology would have almost nothing in common with traditional philosophical anthropology."11

20 The object of materialist anthropology would be man's historically changeable nature. Horkheimer might be willing to subscribe to this definition, but would Adorno? Could he reject conditionality and development as abstract qualities, but allow for man's changeability? The Kantian restriction of empirical realism to the limits of transcendental idealism would refute the assumption of an invariant natural essence, but the categories cannot be independent of social mediation. This implies that orthodox materialism's concept of nature as pre-existing and ineluctable does not apply to human "nature", but still supports the refutation of the human being's transcendence. ${ }^{12}$ Based on these stipulations, Adorno's dialectical anthropology would conceive of nature as being mediated by subjectivity, but reject the idea that the laws of this mediation are absolute. Rather, they are shaped by the objective development of social conditions. If these conditions change, our concept of nature changes too.

21 If there is no transcendence of man and his self-understanding, then the relationship between history and nature can only be understood on the basis of a "secular category" (Adorno 1983: 360). Adorno adopts Benjamin's concept of "nature-history" from the Origin of German Tragic Drama - the idea, in his words, that "the moment in which nature 
and history become commensurable with each other is the moment of decay (Vergängnis)" (ibid.: 359; transl. changed). With the help of this category, Adorno (1984: 111) intends to "dialectically overcome the usual antithesis of nature and history." Les extrêmes se touchent. Like Adorno's dialectical philosophy, dialectical anthropology has to increase the oscillation of the oppositions without conflating them altogether; it has to " comprehend historical being in its most extreme historical determinacy, where it is most historical, as natural being," and at the same time "comprehend nature as an [sic] historical being where it seems to rest most deeply in itself as nature" (ibid.: 117; italics in the original).

What Adorno tries to overcome is the same antithesis Marquard (1973:138-144) describes as the alternative of philosophical anthropology and philosophy of history. However, Adorno does not explicate his understanding of dialectical anthropology, and he does not address the way in which nature and history relate to each other within the concept of man. The question of this relationship is the inheritance of Kant's separation of man's empirical and noumenal registers. Adorno rejects all philosophical anthropology instead of confronting the way in which it complicates the antithesis of nature and history. For him, there is no proper object of theoretical anthropology, neither human essence nor its historical openness and changeability.

\section{Sonnemann. Permanent anthropological revolution}

In the preface to Negative Dialectics, Adorno (1973: 11) calls it a coincidence dictated by the subject matter that his friend Ulrich Sonnemann was working on a book with the strikingly similar title, Negative Anthropologie. ${ }^{13}$ In his short review of the book, Adorno (1970: 263) describes it as being permeated by the "critical processes" that caused anthropology to withdraw from the philosophical aspirations it pursued during the 1910s and 1920s. However, as Adorno also notes, Sonnemann's main focus is not the tradition of philosophical anthropology, but the relationship between Freud and Marx.

Horkheimer's essay from 1935 has started these critical processes. 35 years later, Adorno (ibid.; own translations) contends, Sonnemann's book resumes the "cancelled and fractured discussion of anthropology". His contribution, according to Adorno, is to depict psychoanalysis and Marxism - "the last two great conceptions that dealt with the concept of man" - not as two complementary instruments that work together, but as two opposed efforts that both failed because they could not come to terms with each other. They can only break the spell of anthropological philosophy's "monistic construction from a principle" by mutually "defetishising" each other. Such defetishisation, according to Adorno, requires that psychoanalysis and historical materialism both abandon their positive anthropological assumptions, and instead understand man on the basis of his denial and absence.

For Sonnemann himself, the failure of Marxism and psychoanalysis is rooted in a single modern epistemological misconception. Instrumental reason's cunning and uncompromising self-preservation is the Leitmotiv of his Negative Anthropologie. Theory and praxis have to reflect their mutual entwinement, or they will inevitably fail, which is much more fatal for social praxis than for theory. ${ }^{14}$ Sonnemann (1969: 22) maintains that "deficient anthropology" was responsible for the "failure of the Marxist revolutions even where they were triumphant in the beginning." 15 Marx, whom Sonnemann (2011: 375) subsumes under the category of positive anthropology, was deceived by the image ( Modellbild) of man; he did not see that his "new man" depends on the image of the human 
being as it is given in the present historical condition. Since the new man cannot be demonstrated in any concrete historical situation, and always assumes the shape of the present's phantasies, Sonnemann (1969: 22) concludes that the "design of man's possibilities" cannot be called "anthropology in the positive sense of the word". Consequently, he defines negative anthropology as the "demonstration of the logical impossibility of any total theory (Totaltheorie) of man."

In discussing, among others, Descartes, Kant, and Nicholas of Cusa, Sonnemann seeks to cast doubt on the assumption that the human being is a legitimate object of scientific and philosophical inquiry. His main preoccupation is that from the perspective of anthropological philosophy, man is at the same time the creator of epistemological criteria and the object to which these criteria are applied. Sonnemann (1987: 16) is convinced, however, that the conditions of object experience, or "Objekterfahrung", cannot themselves be the object of knowledge.

Sonnemann's conception rests on the premise that what blocks the realisation of reasonable social circumstances is not the existing corrupt reality, but the abstract images of how these circumstances could or should look like. ${ }^{16}$ Every teleological model emerges from historically determined forms of consciousness, unable to transcend the limitations of the present. What Sonnemann (1969: 136-137) worries about is the paradox that man is both the object and subject of cognition. In this circular structure, or "Kreislauf", positive anthropology causes what he calls a short circuit, an infinite regression that corrupts historical materialism and psychoanalysis, eventually causing revolutionary practice to fail.

Although Negative Anthropologie is not a philosophical anthropology sui generis, it is more programmatic than the rudiments of a dialectical anthropology found in Horkheimer and Adorno. They agree that the human being is not something unfinished or inconclusive; it is not an eligible object of theoretical philosophy at all. However, since it assumes this status as long as modern epistemology forces man to inquire about the condition of his self-knowledge, negative anthropology must work on disproving its efforts of giving conclusive explanations.

Sonnemann believes the ban on philosophical anthropology can and has to be more than normative. In his eyes, the assumption that man can achieve complete and conclusive self-knowledge is a logical error capable of proving theoretical anthropology's epistemological impossibility. He does not claim to have provided such a proof, but he called the task by its name, and he intended to pave the road for a "permanent anthropological revolution" (Sonnemann 2011: 361). "Human beings", concludes his thesis, "cannot say what they are, because they become what they think" (1969: 324).

\section{Conclusion}

In his introduction to Kant's Anthropology from a Pragmatic Point of View, Michel Foucault (2008) comes to the conclusion that what Kant presents as an antinomy solvable by transcendental philosophy is actually an aporia in the centre of the anthropological question itself: in respect to the human being, the empirical and transcendental can never reach congruence. The theoretical striving for this congruence, Sonnemann (1969: 22-23) contends, originated in an epoch where reason did not yet despair of itself, and this despair is a welcome progress. 
31 The more reason's self-doubt is embraced, the more carefully the anthropological question can be approached. Since assumptions about the essence of man are an integral part of the scientific outlook of modernity, they have to be criticised permanently. In view of such a critical project, Horkheimer provides reasons for why the anthropological question should not be answered on metaphysical grounds alone. If it wants to be of any value for Critical Theory, philosophical anthropology has to be limited to studying the way in which social relations engender and shape specific historical human conditions.

Adorno, allegedly more radical than Horkheimer in this respect, claims to refute the legitimacy of theoretical anthropology as such. Like Horkheimer, Adorno gives good reasons for why the question "What is man?" should not be answered, but its epistemological impossibility - the question whether or not it can be answered - remains an open issue. Adorno's negative dialectics aim to overcome the antithesis between nature and history, but he does not consider this antithesis as an immanent question of anthropology.

Sonnemann realises negative anthropology as a critical programme based on the conviction that positive anthropology hinders social praxis. He seeks to mobilise subjective spontaneity against any totalising theories of man. By leaving man's condition undetermined, negative anthropology seeks to destroy images of future human conditions that block the way to an alteration of the present.

In many ways, the early Frankfurt School's altercation with philosophical anthropology unearths an implicit tension between Kant and Marx. What Marx (1982: 254; 739) calls man's "boundless drive for enrichment, or "absoluter Bereicherungstrieb", is what Kant (1963: 15) understands as the human being's natural disposition, or "Naturanlage": the twofold urge to "associate with" and to "isolate [...] from others". For Kant, the principle of nature is antagonism striving towards harmony, not harmony threatened by antagonism. "The means employed by nature to bring about the development of all the capacities of men is their anatagonism in society" - or, to use Kant's formula: "unsocial sociability" (ibid.).

For Horkheimer, Adorno, and Sonnemann, the stipulation of a natural disposition to isolate oneself from others - to achieve, "propelled by vainglory, lust for power, and avarice, [...] a rank among his fellows" (ibid.) - results from confusing what is invariant in man with what is learned and socially conditioned. Negative anthropology targets the assumption's root: the idea of natural human disposition. It deciphers man's inclination towards isolation as nothing more than the child's unconscious internalisation of the prevailing socio-economic order, rehearsed in the sandboxes of public schoolyards.

\section{BIBLIOGRAPHY}

Adorno, T.W. 1967. Sociology and Psychology (Part I). New Left Review I/46, 67-80.

Adorno, T.W. 1970. Zu Ulrich Sonnemanns "Negativer Anthropologie”. In Gesammelte Schriften. (ed.) R. Tiedemann, Vol. 20.1, 262-263. Frankfurt am Main: Suhrkamp. 
Adorno. T.W. 1973. Negative Dialektik. In Gesammelte Schriften. (ed.) R. Tiedemann, Vol. 6. Frankfurt am Main: Suhrkamp.

Adorno, T.W. 1983. Negative Dialectics. (tr.) E.B. Ashton. New York: Continuum.

Adorno, T.W. 1984. The Idea of Natural History. (tr.) B. Hullot-Kentor. Telos 60, 111-124.

Adorno, T.W. 2003. Education after Auschwitz. In Can one live after Auschwitz? A philosophical reader. (ed.) R. Tiedemann, 19-33. Stanford: Stanford University Press.

Adorno, T.W. 2003a. Individuum und Gesellschaft. Entwürfe und Skizzen. In Frankfurter Adorno Blätter VIII, 60-94. (ed.) R. Tiedemann. München: Text + Kritik.

Adorno, T.W. 2005. Minima Moralia: Reflections on a Damaged Life. (tr.) E.F.N. Jephcott. London/New York: Verso.

Adorno, T.W. 2007. Vorlesung über Negative Dialektik. Fragmente zur Vorlesung 1965/66. (ed.) R.

Tiedemann. Frankfurt am Main: Suhrkamp.

Adorno, T.W. 2008. Lectures on Negative Dialectics. Fragments of a lecture course 1965/1966. (tr.)

R. Livingstone. Malden, MA.: Polity Press.

Adorno, T.W./Horkheimer, M. 2001. Dialectic of Enlightenment: Philosophical Fragments. (ed.) G. Schmidt Noerr. (tr.) E. Jephcott. Stanford: Stanford University Press.

Bien, J. 1984. History, Revolution, and Human Nature. Marx's Philosophical Anthropology. Amsterdam: B.R. Grüner.

Brandt, R. 1999. Kritischer Kommentar zu Kants Anthropologie in pragmatischer Hinsicht (1798). Hamburg: Meiner.

Breuer, S. 1985. Adornos Anthropologie. In Aspekte totaler Vergesellschaftung, 34-51. Freiburg: ÇaIra.

Engels, L. 1997. Feuerbach and the End of Classical German Philosophy. In German Socialist Philosophy. Ludwig Feuerbach, Karl Marx, Friedrich Engels. (ed.) W. Schirmacher, 183-207. New York: Continuum Publishing.

Fischer, J. 2008. Philosophische Anthropologie. Eine Denkrichtung des 20. Jahrhunderts. Freiburg: Alber.

Foucault, M. 2008. Introduction to Kant's Anthropology. (tr.) R. Nigro/K. Briggs. Los Angeles: Semiotext(e).

Gebauer, G./Kamper, D./Lenzen, D. et al. (ed.). 1989. Historische Anthropologie. Zum Problem der Humanwissenschaften heute oder Versuche einer Neubegründung. Reinbek bei Hamburg: Rowohlt.

Habermas, J. 1973. Philosophische Anthropologie (ein Lexikonartikel) 1958. In Kultur und Kritik. Verstreute Aufsätze, 89-111. Frankfurt am Main: Suhrkamp.

Horkheimer, M. 1974. The Concept of Man. In Critique of Instrumental Reason. Lectures and Essays since the End of World War II, 1-33. New York: Seabury Press.

Horkheimer, M. 1995. Remarks on Philosophical Anthropology. In Between Philosophy and Social Science. Selected Early Writings, 151-176. Cambridge, MA: MIT Press.

Jay, M. 1973. The Dialectical Imagination. A History of the Frankfurt School and the Institute of Social Research 1923-1950. Boston, Toronto: Little, Brown and Company. 
Kamper, D. 1973. Geschichte und menschliche Natur. Die Tragweite gegenwärtiger Anthropologiekritik. München: Hanser.

Kant, I. 1963. On History. (ed.) L. White Beck. Upper Saddle River, New Jersey: Prentice Hall. Kant, I. 1992. Lectures on logic. (tr.) M. Young. Cambridge: Cambridge University Press.

Kant, I. 1997. Lectures on ethics. (tr.) P. Heath. Cambridge: Cambridge University Press.

Kant, I. 2007. Anthropology, History, and Education. (ed.) G. Zöller/R.B. Louden. Cambridge: Cambridge University Press.

Kofler, L. 1967. Der asketische Eros. Industriekultur und Ideologie. Wien: Europa-Verlag.

Kofler, L. 1973. Aggression und Gewissen. Grundlegung einer anthropologischen

Erkenntnistheorie. München: Hanser.

Lukács, G. 1971. History and Class Consciousness. Studies in Marxist Dialectics. (tr.) R. Livingstone. Cambridge, MA: MIT Press.

Marcuse, H. 1936. Zum Begriff des Wesens. Zeitschrift für Sozialforschung V/1, 1-39.

Marquard, U. 1973. Zur Geschichte des philosophischen Begriffs “Anthropologie” seit dem Ende des achtzehnten Jahrhunderts. In Schwierigkeiten der Geschichtsphilosophie, 122-144. Frankfurt am Main: Suhrkamp.

Marx, K. 1978. Theses on Feuerbach. In The Marx-Engels Reader. (ed.) R.C. Tucker. 2nd ed. New York/London: W. W. Norton \& Company.

Marx, K. 1982. Capital. A Critique of Political Economy. Vol. 1. (ed.) B. Fowkes. London: Penguin Books.

Marx, K. 1988. Economic and Philosophic Manuscripts of 1844 and the Communist Manifesto. (tr.) M. Milligan. Amherst, NY: Prometheus Books.

Marx, K. 1992. Preface (to A Contribution to the Critique of Political Economy). In Early Writings.

(tr.) R. Livingston/G. Benton, 424-428. London: Penguin.

Plessner, H. 1981. Macht und menschliche Natur. Ein Versuch zur Anthropologie der geschichtlichen Weltansicht. In Gesammelte Schriften. (ed.) G. Dux, Vol. 5., 135-234. Frankfurt am Main: Suhrkamp.

Schmidt, A. 1962. Der Begriff der Natur in der Lehre von Marx. Frankfurt am Main: Europäische Verlagsanstalt.

Schmied-Kowarzik, W. (ed.). 1992. Einsprüche kritischer Philosophie. Kleine Festschrift für Ulrich Sonnemann. Mit einem Gesamtschriftenverzeichnis und einem tabellarischen Lebenslauf von Ulrich Sonnemann. Kassel: Gesamthochschule.

Schmied-Kowarzik, W. 1999. "Spontaneität die denkend in der Geschichte handelt." Eine Skizze zum Denkweg von Ulrich Sonnemann. In Existenz, Negativität und Kritik bei Ulrich Sonnemann. (ed.) C.-V. Klenke (et al.), 20-36. Würzburg: Könighausen \& Neumann.

Sonnemann, U. 1969. Negative Anthropologie. Vorstudien zur Sabotage des Schicksals. Reinbek bei Hamburg: Rowohlt.

Sonnemann, U. 1987. Die Menschenwissenschaften und die Spontaneität (1958). In Tunnelstiche. Reden, Aufzeichnungen und Essays, 14-32. Frankfurt am Main: Athenäum.

Sonnemann, U. 2011. Negative Anthropologie, Spontaneität und Verfügung, Sabotage des Schicksals. In Schriften in 10 Bänden. (ed.) P. Fiebig, Vol. 3. Springer: zu Klampen. 
Stark, W. 2003. Historical Notes and Interpretative Questions about Kant's Lectures on Anthropology. In Essays on Kant's Anthropology (ed.) B. Jacobs/ P. Kain, 15-37. Cambridge: Cambridge University Press.

\section{ENDNOTES}

1. A note on this essay's terminology: In an encyclopedia article from 1958, Jürgen Habermas (1973: 89-90) distinguishes between empirical and philosophical anthropology. Empirical anthropology can be (1) biological anthropology, a branch of zoology that compares the human being to other animals in physiological or morphological terms, or (2) ethnology, often equated with anthropology in the Anglophone world, which studies the social and cultural life of ancient and non-writing cultures. Philosophical anthropology, according to Habermas, designates either (1) the German "philosophische Anthropologie," a more or less unified school of thought represented by, among others, Max Scheler, Helmuth Plessner, and Arnold Gehlen, or (2) a subfield (but not a discipline) of philosophy located somewhere between logic, ethics, and metaphysics that integrates the results of biology, ethnology, sociology, psychology etc. in order to determine (in metaphysical or naturalist terms) the "essence" or "nature" of the human being. Schnädelbach (1984: 219-234) describes early $20^{\text {th }}$-century German philosophical anthropology as a response to philosophy's evolving identity crisis after 1831. Fischer (2008) systematically examines the German "philosophische Anthropologie" as a more or less unified "school of thought". - The numerous usages of "man" and his corresponding "he" throughout this essay are due to the subject matter; they are not meant to be discriminatory in terms of gender distinction or otherwise. - I am grateful to Brandon Woolf, Shane Boyle and Abby Anderton for their patient assistance with the translation of this essay, and to Julia Jarcho for sharing her thoughts on negativity and utopia.

2. In his Lectures on logic, Kant (1992: 538) lists four questions of philosophy in a cosmopolitan sense: "1. What can I know? 2. What ought I to do? 3. What may I hope? 4. What is man? Metaphysics answers the first question, morals the second, religion the third, and anthropology the fourth. Fundamentally, however, we could reckon all of this as anthropology, because the first three questions relate to the last one." Both editions of the Critique of Pure Reason contain only the first three of these questions. By separating empirical psychology from $18^{\text {th }}$-century metaphysics, Kant's first Critique (A 848/B 876) inaugurated anthropology as a problem of and for modern philosophy. For Kant, anthropology could not be part of theoretical philosophy, because the human being is partially an empirical phenomenon of which no a priori knowledge is possible. Only as an applied science can philosophical anthropology acquire "pragmatic knowledge" of man's condition by observing his behaviour and by interpreting his cultural manifestations. Physiology can gain empirical knowledge about man's biophysical constitution about "what nature makes of the human being" - and pragmatic anthropology can acquire knowledge of man as applied practical knowledge, or "Weltkenntnis" (Kant 2007: 231). Such knowledge can serve as an application of moral philosophy. In his Lectures on ethics, Kant (1997: 42) defines practical philosophy as the science of what man should do, and anthropology as the science of what man actually does. These two sciences "are closely connected, and morality cannot exist without anthropology, for one must first know of the agent whether he is also in a position to accomplish what it is required from him that he should do." Kant splits the concept of man. Its empirical reality can only be known on the basis of the pure concepts and principles dictated by transcendental logic. At the same time, these concepts are empty without the intuitions provided by sensibility, and sensibility remains - apart from pure intuitions and, by extension, pure mathematics - tied to man's physiology: the senses. A priori knowledge about the physiological grounds of human sensibility is, strictly speaking, impossible. In Kant's programme 
of critical philosophy, anthropology has its function as applied philosophy, but "human essence" cannot be known a priori. On Kant's pragmatic anthropology, see Brandt (1999), Stark (2003) and Foucault (2008).

3. Several attempts were proposed to understand the historical change of human nature. Marquard (1973: 138) argues that since the late $18^{\text {th }}$ century, philosophy had to decide between nature and history: Turning towards nature and the lifeworld, or "Lebenswelt", implies turning away from history and the realization of freedom - and vice versa. A turn towards the lifeworld made philosophical anthropology possible; by turning away from philosophy of history it became "fundamental." Kamper's (1973: 153) "anthropological difference" describes the impossibility of man's conceptual fixation. Kofler's (1973: 21; 1967: 23-36) "formal anthropology", defined as the "doctrine of the unchangeable preconditions of human changeability", is closest to Marx's early understanding of labour as the metabolism of nature and humanity (Schmidt 1962: 63-78). The metabolism itself is necessary and invariant, but its form changes significantly over the course of history.

4. In History and Class Consciousness, Georg Lukács (1971: 186-187) dismisses anthropology as a philosophical discipline because it reifies the human being's historical possibilities. By "turning philosophy into 'anthropology', he [Ludwig Feuerbach, DJ] caused man to become frozen in a fixed objectivity [...]. And precisely this is the great danger of every 'humanism' or anthropological point of view."

5. Ernst Fromm's and Herbert Marcuse's attempts to combine Marx and Freud raise more specific questions about the relationship between psychology and anthropology that point beyond the scope of this essay. Walter Benjamin's thought also relates differently to the philosophical anthropology of his time. Although he shares many premises with Horhkeimer, Adorno and Sonneman, his work contains a highly idiosyncratic notion of anthropology that cannot be described in the same way as negative anthropology.

6. Martin Jay (1973: 56) points towards these elements when he writes, "in Horkheimer's work there appeared a kind of negative anthropology, an implicit but still powerful presence."

7. Adorno's use of the term "historische Anthropologie" seems to refer to later versions of philosophical anthropology that no longer insist on an undeviating human nature, but still depart from primary assumptions about the essence of man in order to construct coherent theories. This historical anthropology is not to be confused with the Historische Anthropologie of the 1980s and 1990s. Examples of this approach can be found in Gebauer et al. (1989).

8. My own translation. "Die These arrivierter Anthropologie, der Mensch sei offen - selten fehlt ihr der hämische Seitenblick aufs Tier -, ist leer; sie gaukelt ihre eigene Unbestimmtheit, ihr Fallissement, als Bestimmtes und Positives vor" (Adorno 1973: 130). Here, Adorno might think of Plessner's (1981: 188) "relation of indeterminacy": “In dieser Relation der Unbestimmtheit zu sich faßt sich der Mensch als Macht und entdeckt sich für sein Leben, theoretisch und praktisch, als offene Frage."

9. In Minima Moralia (2005: 167), Adorno evokes the notion "negative anthropology" as a description of what the human beings are deprived of by society. Referring to this passage, Breuer (1985: 34) reads Adorno's negative anthropology as the centrepiece of his negative dialectics. Since modern society has subdued and domesticated "first nature" to an extent, that theory can disregard it (35), negative anthropology has to turn to second nature. It consequently becomes a paradox: anthropology without anthropos (50). Although it is true that Adorno disregards any notion of first nature prior to social and conceptual mediation - "Second nature, in truth, is first nature", he wrote as early as 1932 (Adorno 1984: 124) - his veto from Negative Dialectics would apply again: Anthropology without anthropos would be no special anthropology, but the mark of its impossibility. However, Breuer correctly points out that Adorno's verdict is not as exclusive as it seems. 
10. These fragments were presumably written in close proximity to the reflections gathered in the last chapter of the Dialectic of Enlightenment, described by Horkheimer and Adorno (2001: xix) as pertaining to a "dialectical anthropology".

11. My own translation. "Daß es gleichwohl zu keiner abgeschlossenen, dem Druck übergebenen Arbeit [...] gekommen ist, dürfte mit der prinzipiellen Kritik aller außergeschichtlichen Anthropologie zusammenhängen, wie sie bereits in Horkheimers Bemerkungen zur philosophischen Anthropologie von 1935 vorgetragen wird. Während die traditionelle Anthropologie etwa bei Max Scheler von einheitlichen Grundstrukturen des ,Menschseins' ausgeht, hätte eine materialistische Anthropologie, um die allein es der Kritischen Theorie zu tun sein konnte, von der historisch sich ändernden Natur des Menschen zu handeln. Die materialistische Anthropologie hätte mit der traditionellen philosophischen den Namen, sonst kaum noch etwas gemeinsam" (Adorno 2003a: 60).

12. "Nature exists independently of all philosophy. It is the foundation upon which we human beings, ourselves products of nature, have grown up. Nothing exists outside nature and man, and the higher beings our religious fantasies have created are only the fantastic reflection of our own essence" (Engels 1997: 190).

13. Sonnemann's Negative Anthropologie has not been translated into English. For an introduction to Sonnemann's thought, see Schmied-Kowarzik (1999). For bibliographical and biographical information, see Schmied-Kowarzik (1992). The small paragraph that contains Adorno's reference to Sonnemann's book is missing in Ashton's translation of Negative Dialectic.

14. Adorno's "Marginalia to Theory and Praxis", one of his last writings, is dedicated to Sonnemann, and his remarks on dialectical anthropology in the Lectures on Negative Dialectics, mentioned above, also seem to be written with a side glance to his friend's work.

15. All translations from Negative Anthropologie are my own.

16. Adorno expresses the same thought at the end of his Lectures on Negative Dialectics (2008: 181-182): "Knowledge, which desires content, is really in search of utopia. It [utopia, DJ], the consciousness of possibility, clings to whatever has not been disfigured. The way to utopia is barred by the possible, never the immediate reality; this is why it always appears abstract to consciousness [im Bewusstsein]." Transl. changed. German original: "Erkenntnis, die den Inhalt will, meint die Utopie. [...] Sie, das Bewußtsein der Möglichkeit, haftet an dem Unverschandelten. Es ist das Mögliche, niemals das unmittelbar Wirkliche, das ihm den Platz versperrt; darum erscheint es im Bewußtsein immer als abstract" (Adorno 2007: 224).

\section{ABSTRACTS}

Can philosophy say what man is? What is gained or lost by making theoretical assumptions about the human being? This essay examines the "negative anthropology" of the early Frankfurt School by asking how Max Horkheimer, Theodor W. Adorno and Ulrich Sonnemann engage with the question "What is man?" Negative anthropology turns out to be more than the critique of philosophical anthropology: By understanding the human being as the ensemble of what it is not, negative anthropology avoids the predicament of spelling out what it could be, while holding on to the idea of man's self-realization in history. What role does negative anthropology play as a component of critical social theory? To what extent can it count as a theoretical programme? Do certain historical situations demand anthropological assumptions more than others? To address these questions, this essay follows the early Frankfurt School's altercations with anthropological philosophy.

La philosophie peut-elle définir l'essence de l'homme? Que gagne-t-on - ou perd-on - avec des déclarations métaphysiques sur l'être humain ? Cet essai explore l' " anthropologie négative » de 
la première école de Francfort à travers les réponses de Walter Benjamin, Max Horkheimer, Theodor W. Adorno et Ulrich Sonnemann à la question: "qu'est-ce que l'homme»? L'anthropologie négative apparaît alors comme plus qu'une critique de l'anthropologie philosophique. En appréhendant l'homme à travers tout ce qu'il n'est pas, elle évite la situation fâcheuse d'énoncer ce qu'il pourrait être, tout en préservant l'idée d'émancipation. Quel rôle l'anthropologie négative joue-t-elle en tant que composante d'une théorie sociale critique? A quel point compte-t-elle dans son programme théorique? Certaines situations historiques exigent-elles des énoncés anthropologiques plus que d'autres? L'artice présent discute de ces questions en circonscrivant le conflit de la première Ecole de Francfort avec l'anthropologie philosophique.

¿Puede acaso la filosofía determinar la esencia del hombre? ¿Qué se gana o qué se pierde asumiendo determinaciones metafísicas sobre el ser humano? Este ensayo examina la « antropología negativa » de la primera escuela de Frankfurt indagando el modo en que Walter Benjamin, Max Horkheimer, Theodor W. Adorno y Ulrich Sonnemann responden a la pregunta " ¿qué es el hombre?». La antropología negativa aparece entonces como algo más que la crítica de la filosofía antropológica. Al comprender al hombre a partir de todo de lo que él no es, la antropología negativa evita la difícil situación de detallar lo que él podría ser, manteniendo al mismo tiempo la idea de emancipación. ¿Qué rol juega la antropología negativa en tanto componente de la teoría social crítica? ¿Hasta qué punto puede contar como programa teorético? ¿Acaso ciertas situaciones históricas exigen asumir supuestos antropológicos más que otras? Este ensayo discute tales interrogantes siguiendo el conflicto de la primera escuela de Frankfurt con la antropología filosófica.

INDEX

Keywords: critical theory, Frankfurt school, philosophical anthropology, negative anthropology, materialism, Sonnemann Ulrich

Palabras claves: teoría crítica, escuela de Frankfurt, materialismo antropológico, antropología negativa, materialismo

Mots-clés: théorie critique, école de Francfort, matérialisme anthropologique, anthropologie négative, matérialisme

\section{AUTHOR}

\section{DENNIS JOHANNSSEN}

Graduate Student in German Studies and Philosophy at Brown University 